Original Research Paper

\title{
Association of Reproductive Problems and Dairy Cow Productivity in a Farm with an Outbreak of Neosporosis Abortion in Brazil
}

\author{
${ }^{1}$ Francisco Carlos Rodrigues de Oliveira, ${ }^{1}$ Samira Salim Mello Gallo, \\ ${ }^{1}$ Murilo de Oliveira Bôa-Morte and ${ }^{2}$ Nicole Brand Ederli \\ ${ }^{1}$ Laboratório de Sanidade Animal (LSA), Centro de Ciências e Tecnologias Agropecuárias (CCTA), \\ Universidade Estadual do Norte Fluminense (UENF), Campos dos Goytacazes, Brazil \\ ${ }^{2}$ Instituto do Noroeste Fluminense de Educação Superior (INFES), Universidade Federal Fluminense (UFF), \\ Santo Antônio de Pádua, Brazil
}

Article history

Received: 04-07-2018

Revised: $10-10-2018$

Accepted: 01-02-2019

Corresponding Author: Samira Salim Mello Gallo Av. Alberto Lamego, 2000, Parque Califórnia, Campos dos Goytacazes, Rio de Janeiro State, 28013-600, Brazil, Tel: +55 (22) 27397359

Email: samiragallo@yahoo.com.br

\begin{abstract}
Neosporosis is a disease caused by the protozoan Neospora caninum and its only clinical symptom in adult cows is abortion. In order to determine whether $N$. caninum was associated with an outbreak of abortion on a high milk production dairy farm with excellent livestock and health control standards, blood was collected from all the animals in the herd to obtain their serum and perform indirect ELISA. To this end, we followed the procedures of the HerdChek anti-Neospora caninum test kit to obtain epidemiological information about isolated estrus repetition, production, recurrent estrus, isolated abortion and recurrent abortion on the dairy farm. Relative risk and Odds ratio were calculated and all the calculations were performed using SAEG 9.1 software. Of the 111 blood samples collected, $42 \%$ tested seropositive and among the 58 lactating cows, $16(28 \%)$ were seropositive. High milk producing cows were more vulnerable to infection by $N$. caninum getting to have 4.5 lower risk of infection than lower milk producing cows. It was also observed that low milk productivity is associated with protection factor. No association was observed between isolate estrus repetition and seropositive and seronegative animals as well as between the presence of recurrent estrus and positive and negative cows. Significant association was observed between isolated abortion and seropositive and seronegative animals as well as between recurrent abortion and positive and negative animals evaluated. Therefore, we conclude that neosporosis does not interfere in fertility, but this is related strictly to abortions in the herd and this problem is most evident in high milk producing dairy cows.
\end{abstract}

Keywords: Neosporosis, Abortion, Fertility, ELISA

\section{Introduction}

Neospora caninum is an emergent protozoan of the phylum Apicomplexa, which can cause reproductive problems in cows worldwide (Dubey et al., 2007). This parasite is responsible for neosporosis-one of the most important diseases that cause abortions in dairy cows (Gennari, 2004; Guimarães et al., 2004; Goodswen et al., 2013). In Brazil, $N$. caninum has been diagnosed in aborted fetuses since 1999 and in serological surveys of cattle and dogs in different states, as well as in other domesticated and wild animals (Cerqueira-Cézar et al., 2017).
Serological testing, an important tool that can be applied to diagnose infection in herds by detecting specific anti- $N$. caninum antibodies, involves techniques such as Indirect Fluorescence Antibody Test (IFAT), Neospora Agglutination Test (NAT), Enzyme-Linked Immunosorbent Assay (ELISA), rapid Immunochromatographic Test (RIT) and the immunoblotassay (Dubey and Schares, 2006). In Brazil the seroprevalence of $N$. caninum varies with the type of cattle (beef, dairy), different regions, within region and with the type of serological tests used (Cerqueira-Cézar et al., 2017). 
In Latin America, neosporosis is considered an emergent disease in dairy cattle being responsible for economic losses related to abortion (Fávero et al., 2017). Basso et al. (2010) have shown in their study that $N$. caninum is the main cause of reproductive disorders in cows worldwide, including abortion, estrus repetitions and temporary anestrus (Bruhn et al., 2013). Animal age was observed by Guimarães et al. (2004) as a risk factor for $N$. caninum infection, where older animals showed greater seroprevalence, indicating that the horizontal transmission has great influence on the herds. In addition, a study in South America demonstrated that neoporosis in dairy cattle has many more risk factors related to the infection (Moore, 2005). These factors are increasing age of cows (between 2 and 6 years old), as well as the intensive management of dairy cattle in the farm, indicating high rates of horizontal transmission in the herds (Moore, 2005).

The purpose of this study was to determine the frequency of anti- $N$. caninum antibodies and investigate the association between reproductive problems through indicators such as fertility, repetition of isolated and recurrent estrus, presence of isolated and recurrent abortion in the herd, as well as whether milk production interfered in the infection on a Brazilian dairy farm which presented an outbreak of epizootic bovine abortion.

\section{Materials and Methods}

The present research was done in March 2010 in a property located in the municipality of Boa Esperança in the South of Minas Gerais, Brazil. Data collected indicated the occurrence of expressive increase of cows that were aborting in the initial third of gestation. This dairy farm had 200 Girolando cattle raised in a semiintensive system, where cows had access to forage and concentrate in the trough and produced an average $30 \mathrm{~kg}$ of milk/cow/day. The farm has a good management system based on a vaccination program to control diseases such as foot-and-mouth disease, rabies, clostridiosis, mastitis, salmonellosis, brucellosis, leptospirosis, infectious bovine rhinotracheitis (IBR) and Bovine Viral Diarrhea (BVD), which causes abortion and reproductive problems. According to the report of the owner and responsible veterinarian sporadic undiagnosed bovine abortions have occurred, despite the excellent sanitary control of the herd. However, in a short period of time, mainly in the last 6 months, several cases of abortion occurred on the farm, leading the owner to seek help from the Veterinary Hospital of the State University of North Fluminense (UENF) to investigate possible causes.

A history of the dairy farm, containing information on reproduction type, estrus recurrence and abortions was obtained from an epidemiological questionnaire applied to the veterinarian and individual milk production of the cows was obtained from the production control record provided by the owner.
After local antisepsis with $2 \%$ iodinated alcohol solution, blood samples were drawn from the jugular vein of 111 cows, using $40 \times 1.2 \mathrm{~mm}$ size disposable needles and $8.5 \mathrm{~mL}$ tubes with separator gel (BD Vacutainer $^{\circledR}$, New Jersey, EUA). The samples were labeled, placed in isothermal boxes $\left(8-10^{\circ} \mathrm{C}\right)$ and sent to the laboratory of parasitology at UENF, where they were centrifuged at $350 \mathrm{~g}$ for $10 \mathrm{~min}$ to separate the serum. They were then placed in $2.0 \mathrm{~mL}$ screw capped plastic tubes, in duplicate, labeled and stored at $-20^{\circ} \mathrm{C}$ until testing.

The indirect ELISA was used for the detection and titration of anti- $N$. caninum antibodies, following the protocol of the HerdChek anti-Neospora caninum test kit for the detection of anti- $N$. caninum antibodies in ruminants $\left(\right.$ Herdchek $^{\circledR}$, Westbrook, USA). Absorbance values were measured using an ELISA Multiskan EX reader (Thermo Fisher Scientific ${ }^{\circledR}$, Vantaa, Finland) equipped with a $620 \mathrm{~nm}$ wavelength filter.

The relationship between overall reproductive problems (abortion or estrus repetition) and the frequency of anti- $N$. caninum antibodies was assessed by calculating the Relative Risk (Rr) using the $\chi^{2}$ statistical test. The Rr was calculated using Fisher's test with katz approximation to determine whether the frequency of antibodies was associated with cows presenting isolated estrus repetition, recurrent estrus, isolated abortions and recurrent abortions and as well as their influence on milk production. Odds ratio (Or) with $95 \%$ Confidence Intervals (CI) were also calculated to determine the chance of the event happening. All the calculations were performed using System of Statistical Analysis (SAEG 9.1) software.

\section{Results}

Since in the farm was only used artificial insemination, the method of reproduction could not be evaluated as risk in the cases of abortion observed in the present study.

Of the 111 cows evaluated, 46 had anti- $N$. canimum antibodies in their sera, indicating a frequency of $42 \%$ of seropositive animals (Fig. 1). Among the 58 lactating cows, 16 (28\%) were seropositive (Fig. 2).

High milk producing cows (above $24 \mathrm{~kg} /$ day) were more vulnerable to infection by $N$. caninum $(\mathrm{Rr}=4.5158$; IC95\%: 1.8290-11.1494), that is, it has 4.5 lower risk of infection than lower milk producing cows, a fact that is extremely significant in terms of infection $(\mathrm{P}=0.0011)$. It was also observed an association when the analysis was performed by Or (Fig. 2), however, determining that a lower milk production is a protective factor for neosporosis.

No association was observed between isolated estrus repetition and positive and negative animals evaluated by $\mathrm{Rr}=0.8728$ (95\% CI: $0.5575-1.3660)$ with $\mathrm{P}=0.5518$, as well as by OR analysis (Fig. 1). Also, no association between positive and negative cows was observed for the presence of recurrent estrus when $\mathrm{Rr}=1.5568$ (95\% CI: $0.9592-2.5267$ ) was evaluated with $\mathrm{P}=0.0733$, as well as by OR analysis (Fig. 3). 




ELISA test (ELISA kit - Herdcheck ${ }^{\circledR}$, IDEXX laboratories Inc. USA)

$\mathrm{P}=0.5499$ [Or=0.7933 (95\% Cl: 0.3713-1.6948)]

Fig. 1: Relationship of isolated estrus repetition and frequency of anti-Neospora caninum antibodies in Giroland cows of high zootechnical stardard, from a farm with an epizootic abortion, in the city of Boa Esperança, Minas Gerais State, Brazil

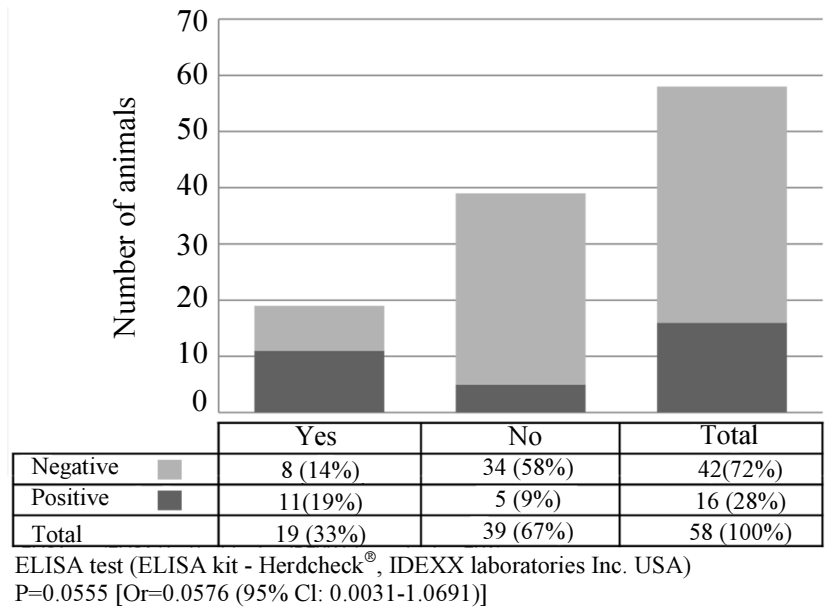

Fig. 2: Relationship of daily production $>24 \mathrm{~kg}$ and frequency of anti-Neospora caninum antibodies in Giroland cows of high zootechnical stardard, from a farm with an epizootic abortion, in the city of Boa Esperança, Minas Gerais State, Brazil



ELISA test (ELISA kit - Herdcheck ${ }^{\circledR}$, IDEXX laboratories Inc. USA)

$\mathrm{P}=0.1242$ [Or $=0.4181(95 \% \mathrm{Cl}: 0.1375-1.2702)]$

Fig. 3: Relationship of recurrent estrus and frequency of anti-Neospora caninum antibodies in Giroland cows of high zootechnical stardard, from a farm with an epizootic abortion, in the city of Boa Esperança, Minas Gerais State, Brazil 


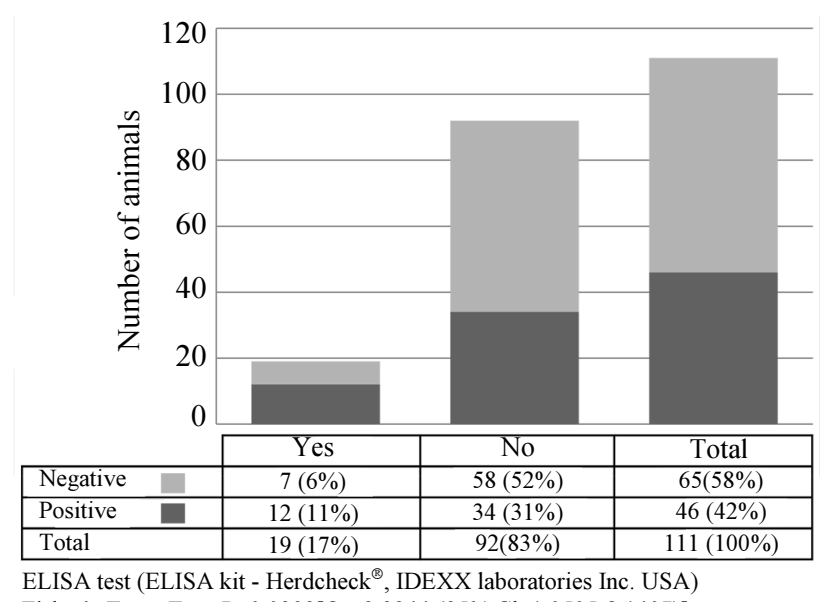

Fisher's Exact Test, $\mathrm{P}=0.0399[\mathrm{Or}=2.9244(95 \% \mathrm{Cl}: 1.0505-8.1407)]$

Fig. 4: Relationship of isolated abortion and frequency of anti-Neospora caninum antibodies in Giroland cows of high zootechnical stardard, from a farm with an epizootic abortion, in the city of Boa Esperança, Minas Gerais State, Brazil



Fig. 5: Relationship of recurrent abortion and frequency of anti-Neospora caninum antibodies in Giroland cows of high zootechnical stardard, from a farm with an epizootic abortion, in the city of Boa Esperança, Minas Gerais State, Brazil

Significant association was observed between isolated abortion and seropositive and seronegative animals evaluated by $\mathrm{Rr}=1.7090$ (95\% CI: 1.1060-2.6402) with $\mathrm{P}=0.0157$. This association is indicating that cows seropositive for $N$. caninum were 1.7 times more likely to abort than seronegative cows. When this association was assessed by the log-normal distribution through Or, it was indicative that the seropositive cows are almost three times more likely to abort than negative cows (Fig. 4).

We also observed an extremely significant association between recurrent abortion and positive and negative animals evaluated by $\mathrm{Rr}=2.5854$ (95\% CI: $2.0343-3.2857$ ) with $\mathrm{P}<0.0001$. This indicated that positive cows were 2.5 times more risk to have recurrent abortion. When we checked this association using Or, it was observed that the chance of recurrent abortion in seropositive cows is not a valid association for cases of neosporosis outbreaks (Fig. 5).

\section{Discussion}

The frequency rates of anti- $N$. caninum antibodies in the serum of dairy cows around the world vary considerably and these rates increase when associated with the occurrence of abortions in herds (Dubey et al., 2007). In this study, the frequency rate of $42 \%$ of seropositive cows was higher than the rates of $23.3 \%$, $19 \%$ and $10.9 \%$ reported, respectively, by Munhoz et al. (2009), Bôa-Morte and Oliveira (2009) and Aguiar et al. (2011) on other Brazilian farms. Including the frequencies observed in the same state where our research was carried out and using the same test (Melo et al., 2004; 2006; Mineo et al., 2006; Bruhn et al., 2013).

These authors carried out their research on cows without actual problems of abortion in the herds. The 
significant difference in the frequency rates observed by these authors, unlike the high frequency rate in the cows of this research, explains the outbreaks of epizootic bovine abortion at the farm under study. The effective disease control program of reproductive problems on the farm, except for neosporosis, reinforces the relationship between abortions and the frequency of anti- $N$. caninum antibodies in the sera of the cows investigated here, which must be a determining factor for the presence of the parasite in the herd.

The non-interference of seropositivity in the repetition of estrus observed in the present research, including in the animals in which this problem is recurrent, is in agreement with authors who have stated that neosporosis does not imply fertility problems (López-Gatius et al., 2005; Brickell et al., 2010; Landmann et al., 2011; GonzalezWarleta et al., 2011). However, although Xia et al. (2011) did not find a significant difference with respect to abortions, the high frequency rate and significant association between abortions in the cows analyzed in this study and the group of seropositive animals are in agreement with the findings reported by Landmann et al. (2011) and Gonzalez-Warleta et al. (2011). This confirms the strong association between this parasite and abortions that occur on several farms where neosporosis is highly frequent, with the Or varying according to the research site and the animal species under analysis, including buffaloes (Nasir et al., 2011), sheeps (Machado et al., 2011) and goats (Topazio et al., 2014), including when in cases of epizootic outbreaks.

According to Aguiar et al. (2011), more productive dairy farms have a higher prevalence of anti- $N$. caninum antibodies, corroborating the findings of this study, which found a significant association between higher milk producing cows and the presence of anti- $N$. caninum antibodies in their sera. Xia et al. (2011) also reported that cattle are more susceptible to disease between 5 and 6 years of age, as cows have their highest production peak in this age group, perhaps this factor is collaborating with the greater seroreactivity of the cows of higher production of our research and of Aguiar et al. (2011). In contrast to this hypothesis, our results when analyzed by the log transformation method determined by Or showed that the lower dairy production of cows is a protection factor (Table 2). This may explain why neosporosis-related problems are not reported in properties with low milk production as occurs in most Brazilian farms (Bôa-Morte and Oliveira, 2009; Munhoz et al., 2009; Aguiar et al., 2011) where production in the vast majority is below $24 \mathrm{~kg}$ of milk per animal per day. In contrast to more developed countries where production losses due to disease are significant (Dubey et al., 2007).

\section{Conclusion}

In this study, we described an epizootic outbreak of neosporosis-related abortion at the farm under investigation. It was also confirmed that neosporosis does not interfere with the fertility of the herd, but is strictly related to abortion and that this problem is more evident in high milk producing cows.

\section{Acknowledgments}

The authors gratefully acknowledge Thomaz Garcia Duque and Clóvis Roberto Duque for their help in collecting blood samples and in obtaining epidemiological data.

\section{Conflicts of Interest}

The authors have no conflicts of interest to declare.

\section{Funding Information}

The authors would like to acknowledge the CNPq (Brazil's National Council for Scientific and Technological Development) for its financial support of this research.

\section{Author's Contributions}

Francisco Carlos Rodrigues de Oliveira: Experimental, design, statistical analysis and writing of the manuscript.

Samira Salim Mello Gallo: Aided in interpreting the results and worked on the manuscript.

Murilo de Oliveira Bôa-Morte: Conducted the experiment, summarized the date.

Nicole Brand Ederli: Worked out almost all of the technical details and worked on the manuscript.

\section{Ethics}

The authors declare there are no ethical issues related to this observational study.

\section{References}

Aguiar, D.M., D.P. Lacerda, R.C. Orlandelli, A.O. Medina and S. Azevedos et al., 2011. Seroprevalence and risk factors associated to Neospora caninum in female bovines from the western São Paulo State, Brazil. Arquivos do Instituto Biológico, 78: 183-189.

Basso, W., S. Schares, L. Minke, A. Barwald and A. Maksimov et al., 2010. Microsatellite typing and avidity analysis suggest a common source of infection in herds with epidemic Neospora caninum associated bovine abortion. Vet. Parasitol., 73: 24-31.

DOI: 10.1016/j.vetpar.2010.06.009 
Bôa-Morte, M.O. and F.C.R. Oliveira, 2009. Frequência de Neosporose em vacas abatidas oriundas da região Norte Fluminense, Estado do Rio de Janeiro, Brasil. RevistaBrasileira de Medicina Veterinária, 31: 13-18.

Brickell, J.S., M.M. McGowan and D.C. Wathes, 2010. Association between Neospora caninum seropositivity and perinatal mortality in dairy heifers at first calving. Veterinary Record, 167: 82-85. DOI:10.1136/vr.c3583

Bruhn, F.R.P., D.O. Daher, E. Lopes, J.M. Barbieri and C.M.B.M. Rocha et al., 2013. Factors associated with seroprevalence of Neospora caninum in dairy cattle in southeastern Brazil. Tropical Animal Health Production, 45: 1093-1098. DOI: $10.1007 / \mathrm{s} 11250-012-0330-y$

Cerqueira-Cézar, C.K., R.C. Bernal, J.P. Dubey and S.M. Gennari, 2017. All about neosporosis in Brazil. Brazilian J. Vet. Parasitology, 26: 253-279.

DOI: 10.1590/S1984-29612017045

Dubey, J.P. and G. Schares, 2006. Diagnosis of bovine neosporosis. Vet. Parasitology, 140: 1-34. DOI: 10.1016/j.vetpar.2006.03.035

Dubey, J.P., G. Schares and L.M. Ortega-Mora, 2007. Epidemiology and control of neosporosis and Neospora caninum. Clinical Microbiol. Rev., 20: 323-367. DOI: 10.1128/CMR.00031-06

Fávero, J.F., A.S. Silva, G. Campigotto and G. Machado et al., 2017. Risk factors for Neospora caninum infection in dairy cattle and their possible cause-effect relation for disease. Microbial Pathogenesis, 110: 202-207.

DOI: 10.1016/j.micpath.2017.06.042

Gennari, S.M., 2004. Neospora caninum no Brasil: Situação atual da pesquisa. Revista Brasileira de Medicina Veterinária, 13: 23-28.

Gonzalez-Warleta, M., J.A. Castro-Hermida, C. CarroCorral and M. Mezo, 2011. Anti-Neospora caninum antibodies in milk in relation to production losses in dairy cattle. Preventive Vet. Medicine, 101: 58-64. DOI: 10.1016/j.prevetmed.2011.04.019

Goodswen, S.J., P.J. Kennedy and J.T. Ellis, 2013. A review of the infection, genetics and evolution of Neospora caninum: From the past to the present. Infection Genetics Evolution, 13: 133-150.

DOI: 10.1016/j.meegid.2012.08.012

Guimarães, J.S., S.L. Souza, D.P. Bergamaschi and S.M. Gennari, 2004. Prevalence of Neospora caninum and factors associated with their presence in dairy cattle of the north of Parana state, Brazil. Vet. Parasitology, 124: 1-8.

DOI: $10.1016 /$ j.vetpar.2004.07.002
Landmann, J.K., A.A. Gunn, P.J. O'donoghue, W.P. Tranter and M.R. McGowan, 2011. Epidemiology and impact of Neospora caninum infection in three Queensland Tropical dairy herds. Reproduction Domestic Animals, 46: 734-737. DOI: 10.1111/j.1439-0531.2010.01712.x

López-Gatius, F., P. Santolaria and S. Almeria, 2005. Neospora caninum infection does not affect the fertility of dairy cows in herds with high incidence of neospora-associated abortions. J. Vet. Med., 52: 51-53. DOI: 10.1111/j.1439-0450.2004.00811.x

Machado, G.P., M. Kikuti, H. Langoni and A.C. Paes, 2011. Seroprevalence and risk factors associated with neosporosis in sheep and dogs from farms. Vet. Parasitol., 182: 356-358. DOI: 10.1016/j.vetpar.2011.05.021

Melo, C.B., R.C. Leite, Z.I.P. Lobato and R.C. Leite, 2004. Infection by Neospora caninum associated with bovine herpesvirus 1 and bovine viral diarrhea virus in cattle from Minas Gerais State, Brazil. Vet. Parasitol., 119: 97-105.

DOI: 10.1016/j.vetpar.2003.12.002

Melo, D.P.G., A.C. Silva, L.M. Ortega-Mora, S.A. Bastos and C.M. Boaventura, 2006. Prevalência de anticorpos anti-Neospora caninum em bovinos das microrregiões de Goiânia e Anápolis, Goiás, Brasil. Revista Brasileira de Parasitologia Veterinária, 15: 105-109.

Mineo, T.W.P., S. Alenius, K. Näslund, H.J. Montassier and C. Björkman, 2006. Distribution of antibodies against Neospora caninum, BVDV and BHV-1 among cows in Brazilian dairy herds with reproductive disorders. Revista Brasileira de Parasitologia Veterinária, 15: 188-192.

Moore, D.P., 2005. Neosporosis in South America. Veterinary Parasitology, 127: 87-97. DOI: 10.1016/j.vetpar.2004.10.001

Munhoz, A.D., M.J.S. Pereira, W. Flausino and C.W.G. Lopes, 2009. Neospora caninum seropositivity in cattle breeds in the South Fluminense Paraíba Valley, State of Rio de Janeiro. Pesquisa Veterinária Brasileira, 29: 29-32. DOI: 10.1590/S0100-736X2009000100004

Nasir, A., M. Ashraf, M.S. Khan, T. Yaqub and A. Javeed et al., 2011. Seroprevalence of Neospora caninum in dairy buffaloes in Lahore District, Pakistan. J. Parasitology, 97: 541-543.

Topazio, J.P., A. Weber, G. Camillo, F.F. Vogel and G. Machado et al., 2014. Seroprevalence and risk factors for Neospora caninum in goats in Santa Catarina state, Brazil. Revista Brasileira de Parasitologia Veterinária, 23: 360-366.

Xia, H.Y., D.H. Zhou, K. Jia, X.B. Zeng and D.W. Zhang et al., 2011. Seroprevalence of Neospora caninum infection in dairy cattle of Southern China. J. Parasitology, 97: 172-173. DOI: $10.1645 / \mathrm{GE}-2643.1$ 